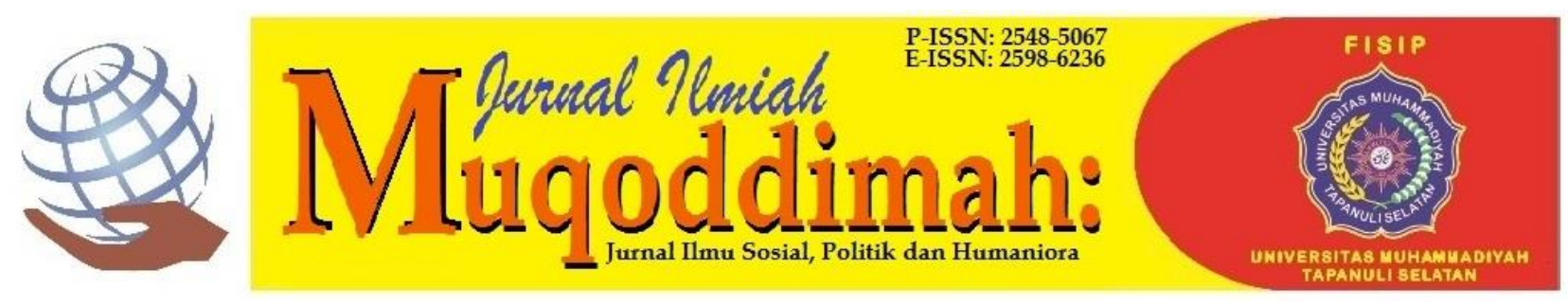

\title{
Komunikasi Kebijakan Publik dalam Membatasi Penggunaan Kantong Plastik di Kota Jambi
}

\author{
Muhaimin $^{1)}$, Noor Khalida2) \\ Prodi Ilmu Komunikasi, Universitas Nurdin Hamzah Jambi \\ Jl. Kolonel Abunjani, Sipin, Kota Jambi, Indonesia \\ muhaimindjuaini@gmail.com¹)
}

\begin{abstract}
Abstrak
Limbah kantong plastik merupakan permasalan umum yang sering dihadapi di kota-kota besar. Pemerintah Kota Jambi sebagai eksekutif telah melakukan kebijakan dan Sosialisasi Peraturan Walikota Jambi Nomor 61 Tahun 2018 tentang Pembatasan penggunaan Kantong Plastik di Kota Jambi. Namun upaya sosialisasi terhadap kebijakan tersebut belum berhasil, kondisi tersebut disebabkan oleh berbagai hal, diantaranya komunikasi kebijakan yang belum diketahui oleh masyarakat dan pelaku usaha. Tujuan dari penelitian ini adalah mendeskripsikan upaya Pemerintah Kota Jambi dalam mengkomunikasikan kebijakan pembatasan penggunaan kantong plastik, menjelaskan media apa yang digunakan, dan mendeskripsikan pengaruh kebijakan pembatasan penggunaan kantong plastik bagi masyarakat. Penelitian ini menggunakan pendekatan kualitatif dengan metode deskriptif, pengumpulan data menggunakan teknik observasi, wawancara, dan dokumentasi. Jumlah sampel 10 orang. Hasil analisis menunjukkan bahwa upaya komunikasi kebijakan pembatasan penggunaan kantong plastik dilakukan melului FGD, melalui Sosialisasi bersama stakeholder atau para pihak terkait, dan melalui himbau dan kampanye. Media yang digunakan adalah bauran media yaitu elektronik, cetak, dan media sosial. Pengaruh kebijakan akan mengurangi penggunaan kantong plastik hingga $30 \%$ sehingga dapat mewujudkan kota Jambi yang bersih, nyaman, dan ramah lingkungan.
\end{abstract}

Kata Kunci: Komunikasi, Kebijakan Publik, Kantong Plastik

\begin{abstract}
Plastic bag waste was a common problem that often faced in a big city. Jambi City Government as an executive had carried out policies and socialization of Jambi Mayor Regulation Number 61 Year 2018 concerning Restrictions on the using of Plastic Bags in Jambi City. However, the efforts to socialize the policy had not been successful; the condition was caused by various things, including policy communication that was not yet known by the public and business actors. The purpose of this study were the first, to describe the efforts of the Jambi City Government in communicating policies to limit the use of plastic bags, the second to explain what kind of media are used, and the third to describe the effect of policies to limit the use of plastic bags. This study used qualitative approach with descriptive method, data collection used observation, interviews, and documentation techniques. The analysis showed that efforts to communicate policies on limiting the use of plastic bags are carried out (FGD), through outreach with stakeholders or related parties, and through appeals and campaigns. The media used is a media mix, namely electronic, print, and social media. The effect of the policy will reduce the use of plastic bags by up to 30\% Those strategies had influenced on people's understanding in order to make Jambi city become clean, comfortable, and friendly environment.
\end{abstract}

Keywords: Communication, Public Policy, Plastic Bags 


\section{PENDAHULUAN}

Provinsi Jambi termasuk salah satu Provinsi di pulau Sumatera yang pembangunan kotanya mengalami perkembangan yang cukup pesat. Perkembangan pembangunan kota Jambi sejalan dengan pertumbuhan penduduknya. Pemicu laju pertumbuhan penduduk karena arus urbanisasi dan juga tingkat kelahiran (penduduk asli) yang cukup tinggi. Bertambahnya jumlah penduduk Kota Jambi tentunya juga berdampak pada limbah rumah tangga. Limbah plastik yang terus bertambah tidak sejalan dengan upaya penjagaan lingkungan. Lingkungan yang sehat akan membuat para penghuninya nyaman dan kesehatan tubuhnya terjaga dengan baik. Kesehatan tubuh manusia berada pada posisi paling utama. Alasannya tentulah kesehatan mempermudah manusia beraktifitas.

Kebersihan lingkungan di Indonesia memiliki masalah serius, terutama dengan kantong plastik. Penggunaan kantong plastik saat ini sangat pesat, tidak hanya di pasar tradisional melainkan juga di pasar modern. Plastik merupakan bahan yang dapat ditemukan pada pembungkus makanan, pembungkus alat elektronik, dan juga pada alat-alat rumah tangga seperti piring, gelas, sendok, dan sebagainya. Pemakaian bahan plastik yang tidak sesuai dengan standar dapat menimbulkan berbagai penyakit pada manusia. Plastik merupakan bahan yang sangat sulit untuk diurai oleh mikro organisme. Selain itu, plastik tidak mudah hancur di dalam tanah sehingga butuh waktu 100 hingga 500 tahun untuk dapat terurai dengan sempurna. Sampah plastik tidaklah bijak jika dibakar karena akan menghasilkan gas yang akan mencemari udara dan membahayakan pernafasan manusia, dan jika sampah plastik ditimbun dalam tanah maka akan mencemari tanah, air tanah (Karuniasturi, 2017).

Pemerintah Kota Jambi telah melakukan beberapa upaya untuk mengatasi beberapa permasalah tersebut dengan mengeluarkan peraturan daerah Kota Jambi Nomor 08 Tahun 2013 tentang Pengelolaan Sampah dan Peraturan Walikota Jambi Nomor 61 Tahun 2018 tentang pembatasan penggunaan Kantong Plastik. Pemerintah sebagai aktor tentunya harus melakukan pembinaan dan pengawasan agar Peraturan Daerah (PERDA) tersebut terlaksana dengan baik. Pembinaan yang akan dilakukan adalah salah satunya dengan cara sosialisasi baik melalui media cetak, media elektronik, media sosial, spanduk, dan binder di tempat-tempat umum, serta melalui organisasi kemasyarakatan dan kepemudaan. Kemudian, pengawasan juga harus dilakukan terhadap pihak produsen, pelaku usaha, penyedia kantong plastik, dan konsumen sebagai pengguna.

Saat ini, penggunaan kantong plastik masih banyak di temukan di pasar tradisional, rumah makan, penyedia plastik, warung, dan pendagang di pinggir jalan (pedagang kaki lima). Pembuangan sampah rumah tangga juga masih banyak menggunakan pembungkus dari plastik daripada kardus. Hal ini memperlihatkan bahwa pembinaan dari Pemerintah terkait pengurangan pemakaian plastik belum maksimal. Sosialisasi yang dilakukan haruslah melibatkan semua pihak dan level social class.

Permasalahan yang ingin diteliti adalah bagaimana upaya Pemerintah Kota mengkomunikasikan kebijakan pembatasan penggunaan kantong plastik; media apa yang digunakan untuk mensosialisasikan kebijakan pembatasan 
penggunaan kantong plastik; bagaimana pengaruh kebijakan pembatasan penggunaan kantong plastik bagi masyarakat. Tujuannya adalah mendeskripsikan upaya Pemerintah Kota mengkomunikasikan kebijakan pembatasan penggunaan kantong plastik; menjelaskan media apa yang digunakan untuk mensosialisasikan kebijakan tersebut; mendeskripsikan pengaruh kebijakan pembatasan penggunaan kantong plastik bagi masyarakat.

Penelitian ini diharapkan bermanfaat bagi perkembangan dunia ilmu Komunikasi, khususnya Kebijakan Publik dalam menyikapi persoalan implementasi kebijakan dari Pemerintah. Informasi dari hasil penelitian ini dapat bermanfaat bagi Pemerintah Daerah untuk memahami lebih jauh hasil kinerja Pemerintah dan pandangan masyarakat tentang kebijakan yang mereka terapkan.

\section{METODE}

Penelitian ini dibagi menjadi tiga tahapan, tahap pertama: pra penelitian, pada tahapan ini peneliti telah melakukan observasi untuk mengumpukan data awal implementasi peraturan Walikota Nomor. 61 Tahun 2018 di Kota Jambi.Tahap kedua, pada tahapan ini penelitian melakukan penelitian lebih mendalam tentang sosialisasi yang dilakukan oleh Pemerinta Kota Jambi dalam mengimplementasikan peraturan Walikota Nomor. 61 Tahun 2018. Tahap ketiga adalah upaya membuktikan benar atau tidaknya kesimpulan yang dibuat melalui verifikasi trianggulasi. Penelitian dilaksanakan di Kota Jambi dengan melibatkan beberapa stakeholder yang dapatmemberikan informasi data terkait dengan permasalahan penelitian.

Jenis penelitian yang digunakan adalah penelitian kualitatif. Penelitian kualitatif adalah suatu proses penelitian dan pemahaman yang berdasarkan pada metodologi yang menyelidiki suatu fenomena sosial dan masalah manusia (Iskandar, 2009). Jadi, penelitian ini memaparkan kondisi real data di lapangan. Kondisi yang terkait dengan tindakan-tindakan yang telah dilakukan Pemerintah untuk pembangunan kota Jambi.

Sedangkan dilihat dari sifatnya, penelitian ini merupakan penelitian deskriktif yaitu penelitian yang bertujuan menggambarkan secara akurat dan sestematis, mengenai setting sosial masalah dan unit yang diteliti. Dalam penelitian ini, peneliti telah memiliki definisi jelas tentang subjek penelitian yang akan digunakan. Metode penelitian lapangan merupakan metode penelitian kualitatif yang dilakukan di tempat atau lokasi di lapangan (Prastowo, 2012). Dalam hal ini penulis secara langsung ke lapangan guna mendapatkan data. Ruang lingkupnya adalah kota Jambi.

Ronny Kountur menyatakan bahwa "populasi adalah suatu kumpulan menyeluruh dari objek yang merupakan perhatian peneliti. Objek penelitian dapat berupa makhluk hidup, benda, sistem, dan prosedur, fenomena, dan lain-lain" (Kountur, 2007). Oleh karena itu, populasi dapat dikatakan juga sebagai keseluruhan dari objek penelitian. Populasi penelitian ini adalah Pemerintah Kota Jambi. Sedangkan sample penelitian ini adalah bagian dari populasi yang masih mempunyai kharakteristik dari penelitian (Kountur, 2007). Jadi, sebagian dari populasi adalah sampel. Sampel pada penelitian ini difokuskan pada Dinas Lingkungan Hidup dan Kehutanan Kota Jambi. 
Pemilihan informan dilakukan dengan menggunakan teknik secara acak, purposive sampling (Endraswara, 2006). Informannya adalah kepala dinas dan Staf pegawai setempat dijadikan informan untuk menemukan solusi dari permasalahan yang ada.

Pada tahap pengumpulan data, penulis menggunakan teknik observasi, wawancara, dan dokumentasi. Observasi berasal dari bahasa latin yang berarti melihat dan memperthatikan; istilah observasi diarahkan pada kegiatan memperthatian secara akurat, mencatat fenomena yang muncul, dan mempertimbangkan hubungan ataraspek dalam fenomena tersebut (Rahayu, 2004). Observasi berarti melakukan pengamatan terhadap objek yang akan diteliti. Wawancara adalah suatu proses tanya jawab lisan, dimana dua orang tau lebih berhadapan secara fisik, yang satu dapat melihat muka yang lain dengan mendengarkan suaranya dengan telinganya sendiri (Rahayu, 2004). Wawancara dilakukan untuk mencari informasi yang lebih dalam terhadap permasalahan yang sedang diteliti. Selanjutnya melakukan dokumentasi. Dukumen adalah metode pengumpualan data berupa dukumen-dukumen, catatan-catatan, transkip, buku-buku, surat kabar, atau anggota dan sebagainya. Data baik berupa catatan atau spanduk tentang pengurangan pemakaian kantong plastik akan dijadikan sumber informasi tambahan.

Analisis data penelitian ini berupa proses pengkajian dari hasil wawancara, pengamatan, dan dokumen yang telah terkumpul. Analisis Penelitian ini bersifat terbuka, open-ended, dan induktif (Rahayu, 2004). Maksudnya, analisis bersifat longgar, tidak kaku, dan tidak statis. Jadi teknik analisis data dalam penelitian menggunakan teknik deskriptif.

\section{HASIL DAN PEMBAHASAN Komunikasikan Kebijakan}

Kebijakan pada dasarnya merupakan ketentuan-ketentuan yang telah ditetapkan oleh Pemerintah Kota Jambi untuk dijadikan pedoman, pegangan atau petunjuk dalam pengembangan ataupun pelaksanaan program dan kegiatan guna tercapainya keterpaduan dalam mewujudkan sasaran, tujuan serta visi Kota Jambi, yaitu: Menjadikan Kota Jambi sebagai pusat perdagangan dan jasa berbasis masyarakat berakhlak dan berbudaya dengan mengedepankan pelayanan prima, dengan misi dibidang lingkungan yaitu ; penguatan pengelolaan infrastruktur dan utilitas perkotaan serta penataan lingkungan. Melalui visi dan Misi inilah Pemerintah Kota Jambi melakukan kebijakan pengurangan maupun larangan penggunaan kantong plastik, khusus mal dan retail pada Januari 2019. Hal itu tertuang dalam Peraturan Wali Kota (Perwal) Nomor 61 tahun 2018 tentang pembatasan penggunaan kantong plastik.

Kebijakan terhadap pengelolaan dan Pembatasan kantong plastik di kota Jambi berpedoman pada (a) Peraturan Daerah Kota Jambi Nomor 8 Tahun 2013 Tentang Pengelolaan Sampah, (b) Peraturan Wali Kota Jambi Nomor 54 Tahun 2018 tentang kebijakan dan strategi kota jambi dalam pengelolaan sampah rumah tangga dan sampah sejenis rumah tangga, dan (c) Peraturan Wali Kota Jambi nomor 61 tahun 2018 tentang pembatasan penggunaan kantong plastik. Adapaun tujuan dari pengaturan terhadap pembatasan penggunaan kantong belanja plastik ini adalah: (1) melindungi Daerah dari 
pencemaran dan/atau kerusakan lingkungan yang diakibatkan oleh penggunaan kantong belanja plastik; (2) menjamin keselamatan, kesehatan dan kehidupan masyarakat Daerah dari ancaman pencemaran dan/atau kerusakan lingkungan hidup yang disebabkan oleh penggunaan kantong belanja plastik; (3) menjamin terpenuhinya keadilan generasi sekarang dan generasi masa depan dalam penggunaan kantong belanja plastik; dan (4) menjamin pemenuhan dan perlindungan hak atas lingkungan hidup yang baik dan sehat bagi masyarakat Daerah akibat penggunaan kantong belanja plastik.

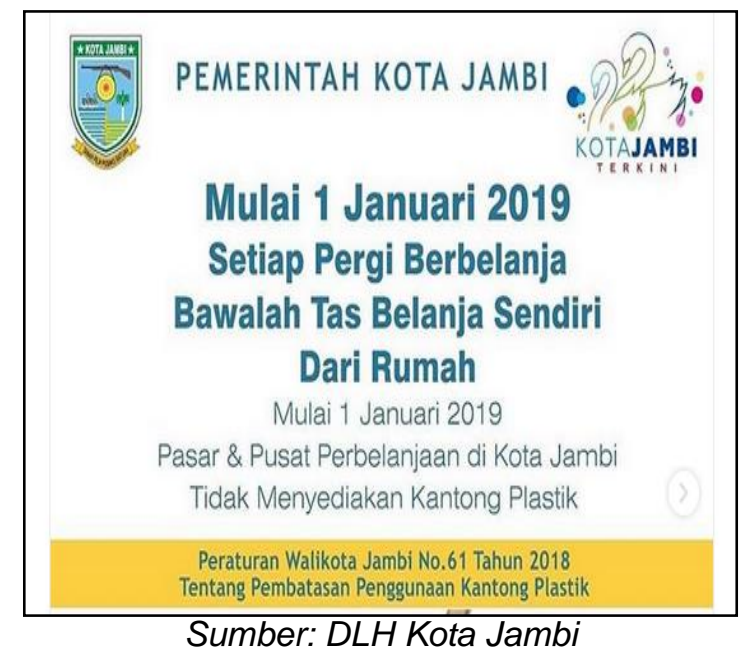

Gambar 1: Poster di Tempat Perbelanjaan

Peraturan Walikota ini sebagai penguat Peraturan Daerah Nomor 8 Tahun 2013 tentang Pengelolaan Sampah. Maka dari itu, untuk menjalankan strategi tersebut. Pemerintah Kota Jambi membuat suatu kebijakan yang diawali dengan pengurangan penggunaan kantong plastik, hingga nantinya larangan, yang berlaku di awal Januari 2019. berdasarkan amanat dari kebijakan strategi daerah dan kebijakan strategi nasional, pengurangan timbulan sampah jenis plastik ini akan mencapai sampai 30 persen pada 2025 mendatang. Pengurangan sampah plastik juga berdampak buruk bagi lingkungan dimasa mendatang. Oleh karena itu, diharapkan masyarakat dapat mendukung pelaksanaan program ini agar timbunan sampah yang dihasilkan dari kantong plastik dapat diminimalkan di Kota Jambi dimasa-masa yang akan datang.

Terdapat tiga indikator yang dipakai (atau digunakan) oleh Pemerintah Kota Jambi dalam mengukur keberhasilan variabel komunikasi terhadap kebijakan pembatasan kantong Plastik di Kota Jambi, yaitu: (1) Transmisi; yaitu penyaluran komunikasi yang baik untuk dapat menghasilkan suatu implementasi yang baik pula. Seringkali yang terjadi dalam penyaluran komunikasi adalah adanya salah pengertian (miskomunikasi), hal ini disebabkan karena komunikasi telah melalui beberapa tingkatan birokrasi sehingga apa yang diharapkan terdistorsi di tengah jalan. (2) Kejelasan; komunikasi yang diterima oleh para pelaksana kebijakan (street-levelbureuacrats) haruslah jelas dan tidak membingungkan (tidak ambigu). Ketidakjelasan pesan kebijakan tidak selalu menghalangi implementasi, pada tataran tertentu, namun para pelaksana membutuhkan kejelasan informasi 
dalam melaksanakan kebijakan agar tujuan yang hendak dicapai dapat diraih sesuai konten kebijakan. (3) Konsistensi; perintah yang diberikan dalam pelaksanaan suatu komunikasi haruslah konsisten (untuk diterapkan dan dijalankan). Ini karena jika perintah yang diberikan sering berubah-ubah, maka dapat menimbulkan kebingungan bagi pelaksana di lapangan.

Komunikasi kebijakan dilakukan melalui berbagai upaya diantaranya adalah kegiatan Forum Group Discussion (FGD) untuk membahas rencana menjalankan strategi mengimplementasikan kebijakan yang diawali dengan pengurangan penggunaan kantong plastik oleh pusat perbelanjaan dan toko modern. Selanjutnya adalah melalui Sosialisasi bersama stakeholder atau para pihak terkait seperti Alfamart, Indomaret, Hypermart, Lippomall, Jamtos, Mandala dan lain-lain yang pada prinsipnya para pihak mendukung rencana pemerintah daerah. Sosialisasinya telah dilaksanakan sejak Oktober 2018, Pemerintah Kota Jambi melali Dinas Lingkungan Hidup telah memanggil semua pengelola ritel, Alfamart, Indomaret dan lainnya. Mereka sudah setuju untuk tidak menggunakan sampah plastik di Kota Jambi. Sehingga Terhitung tanggal 1 Januari 2019, pusat perbelanjaan modern dan ritel, dilarang menyediakan kantong plastik bagi konsumen.

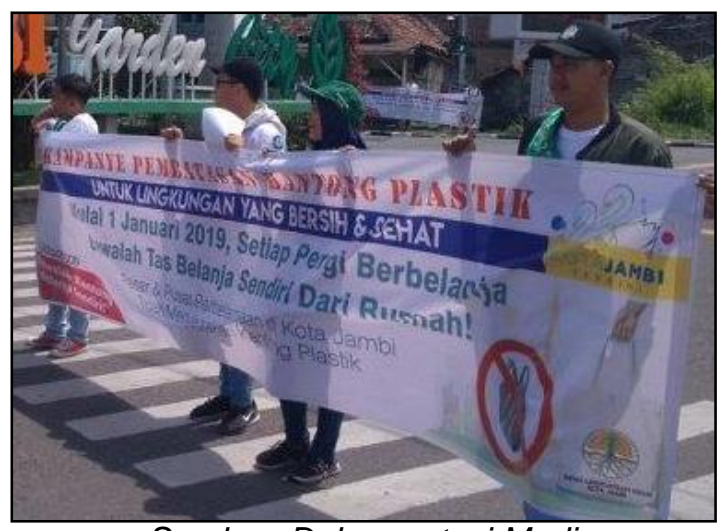

Sumber: Dokumentasi Media

Gambar 2: Kampanye diet plastik

Komunikasi kebijakan juga dilakukan melalui himbauan kepada masyarakat untuk membawa kantong belanja sendiri dan melalui kampanye pembatasan penggunaan kantong plastik dengan menggunakan media komunikasi.

\section{Media}

Sebagai persiapan dalam pelaksanaan kebijakan maka para implementor terlebih dahulu memahami kebijakan pengelolaan kantong plastik tersebut dengan melakukan interpretasi. Interpretasi dilakukan oleh para implementor, yaitu Dinas Lingkungan Hidup dan Dinas Kebersihan Kota Jambi untuk melakukan analisis pemahaman terhadap sebuah kebijakan yang masih bersifat abstrak ke dalam kebijakan yang lebih bersifat teknis operasional. Kebijakan umum atau kebijakan strategis (strategic policy) akan dijabarkan ke dalam kebijakan manajerial (managerial policy) dan kebijakan manajerial akan dijabarkan dalam kebijakan teknis operasional (operational policy). 
Pemerintah Kota Jambi melalui Dinas Lingkungan Hidup (DLH) Kota Jambi telah melakukan sosialisasi, terhadap pembatasan penggunaan kantong plastik di Kota Jambi. Proses sosialisasi merupakan salah satu bentuk komunikasi kebijakan yang efektif dengan berbagai pemangku kepentingan. Komunikasi ini sebenarnya bisa dilakukan melalui berbagai cara baik secara interpersonal, komunikasi kelompok maupun melalui media massa.

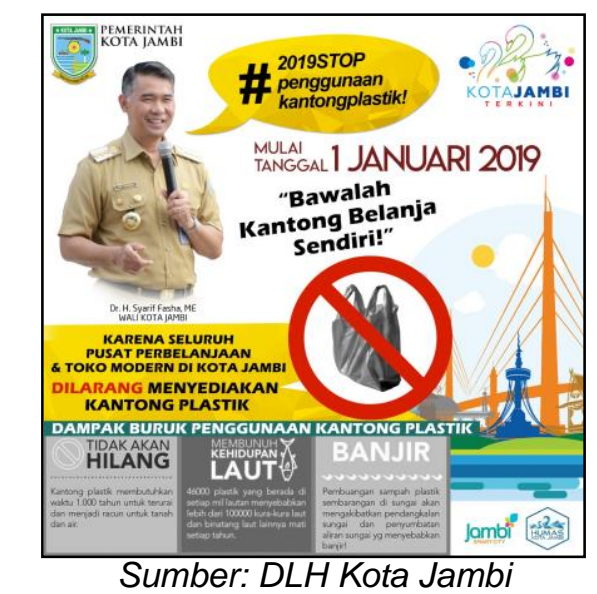

Gambar 3: Poster di Media Cetak

Strategi bauran media (mix media) pada dasarnya bertumpu pada strategi komunikasi dan relasi. Melalui bauran media (mix media) sebuah instansi Pemerintah dapat berkomunikasi dan menjalin relasi dengan pemangku kepentingan (stakeholders) masyarakat. Dalam menjalin komunikasi dan relasi dengan pemangku kepentingan (stakeholders) instasi Pemerintah memerlukan media sebagai alat komunikasi. Karena itu, strategi bauran media (mix media) menjadi suatu yang penting dalam membangun relasi dengan masyarakat.

Dari data wawancara beberapa stakeholders memberikan masukan bahwa ada beberapa proritas media yang paling efektif dan dapat digunakan untuk menjembatani komunikasi antara Pemerintah Kota Jambi dengan pihak stakeholdernya. Media-media tersebut terbagi dalam dua kategori yaitu media elektronik dan media cetak. Adapun media elektronik di klasifikasi menjadi beberapa jenis yaitu televisi, radio. sedangkan media cetak seperti koran dan majalah.

Media elektronika merupakan media yang muncul setelah media cetak. Walaupun perkembangan media elektronika sangat pesat tidak dengan sendirinya mematikan media cetak. Antara media cetak dan media elektronika saling melengkapi. Media yang termasuk ke dalam media elektronik, adalah (1) siaran radio yang bersifat auditif sehingga kita dituntut membayangkan apa yang disajikan melalui siaran radio, (2) siaran televisi yang bersifat audiovisual yang membuat kita tak perlu membayangkan lagi apa yang disampaikan siaran televisi karena sudah ada visualisasinya dan (3) Film, yaitu gambar bergerak yang merupakan bentuk dominan dari komunikasi massa visual. Film adalah media yang lebih banyak bersifat hiburan. Karenanya, orang menonton film ke bioskop mempunyai tujuan utama untuk 
memperoleh hiburan. Namun, ada juga beberapa film yang dibuat untuk keperluan informatif dan persuasif. Disamping mempunyai kelebihan yang tidak didapat dari media cetak, ketiga media elektronik tersebut memiliki kelemahan, yaitu informasi yang disajikan umumnya lebih ringkas. Selain itu, jika kita terlewat dalam penerimaan suatu pesan, kita tidak bisa mengulanginya lagi. Berbeda dengan media cetak, yang dapat dibaca berulang-ulang, jika ada bagian yang belum/tidak begitu kita pahami. Surat kabar dapat kita baca kapan saja kita mau.

Dari sisi kecepatan, Siaran media elektronik seperti radio dan televisi bahkan bisa menyajikan informasi pada saat peristiwanya sedang berlangsung, Semua media tersebut dapat berfungsi secara optimal tergantung dari berbagai faktor yang mempengaruhinya, seperti faktor waktu atau jadwal penayangan dan juga jenis program yang disiarkan.

Hampir seluruh wilayah di Kota Jambi dapat menerima siaran dari beberapa televisi lokal seperti Jambi TV, Jek TV, dan TVRI Jambi. Jadi Pemerintah Kota Jambi dapat merintis jalinan komunikasi yang harmonis dengan masyarakat dan tidak perlu mengeluarkan banyak modal untuk membuat stasiun televisi sendiri. Jenis program ataupun pesan yang dapat disampaikan melalui, JambiTV, JekTV, TVRI Jambi, cukup beragam antara lain: pertama, menyangkut perkembangan dan program Pemerintah untuk masyarakat, kedua, iklan layanan masyarakat (info lowongan pekerjaan, info pendidikan, dan info program Pemerintah), dan ketiga, dialog interaktif yang mengangkat pesan keterbukaan info publik terhadap program Pemerintah.

Dari data wawancara beberapa stakeholders juga memberikan masukan untuk menggunakan berbagai radio sebagai alat komunikasi (communication tools). Beberapa radio yang ditawarkan antara lain RRI Jambi, dan Eldity $\mathrm{Fm}$. Jenis program dibedakan antara radio yang satu dengan yang lain. RRI Jambi dengan program dialog interaktif (melibatkan pendengar dan narasumber), sedangkan Eldity Fm mengangkat program hiburan dan iklan layanan masyarakat ataupun request on the air.

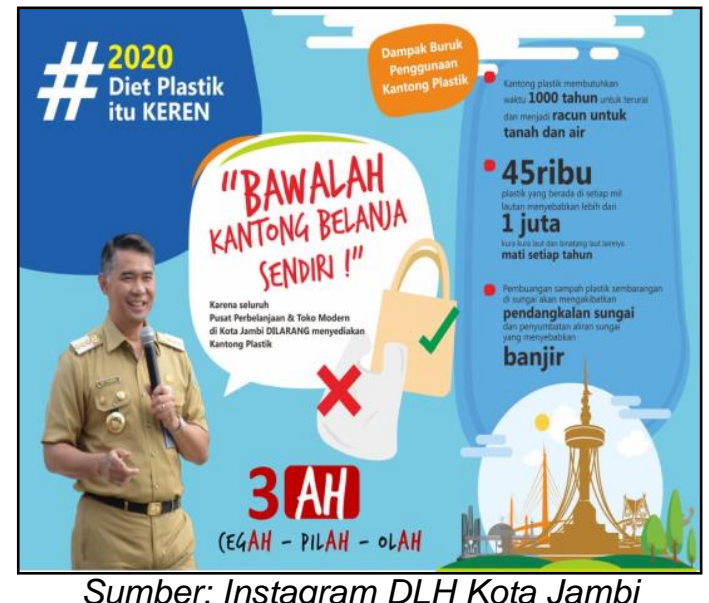

Gambar 4: Poster di Media Sosial

Media lain yang bisa dijadikan sarana komunikasi leh Pemerintah Kota Jambi adalah media sosial. Menurut Ettredge (2001) keuntungan menggunakan media sosial untuk komunikasi karena mempunyai dimensi 
ketepatan waktu (timely). Selanjutnya menurut Williams (2000) melalui internet informasi dapat dengan segera tersedia (real time), kemampuan komunikasi global dan jangkaun global yang dimiliki oleh media sosial memungkinkan informasi dapat diakses oleh berbagai pemangku kepentingan, dan website juga memungkinan komunikasi dua arah dan umpan balik melalui surat elektronik, forum diskusi, dan buletin boards. Pada dasarnya, dengan menggunakan jaringan internet, program-program Pemerintah dapat dan memungkinan dapat diakses oleh masyarakat.

Media sosial yang digunakan dalam mensosialisasikan kebijakan pembatasan Kantong Plastik di Kota Jambi diantaranya adalah (1) Facebook; melalui akun facebook humas Pemerintah Kota Jambi memberikan postinganan-postingan yang menjelaskan program sosialisasi Gerakan Diet Katong Plastik. (2) Instagram; melalui akun @humaskotajambi memposting berbagai slogan, video, meme, dan karikatur yang memuat pesan ajakan Diet penggunaan kantong plastic. (3) Website resmi; melalui laman website jambikota.go.id pemerintah menyampaikan postingan pesan dan anjuran kepada masyarakat untuk membawa kantong belanja sendiri.

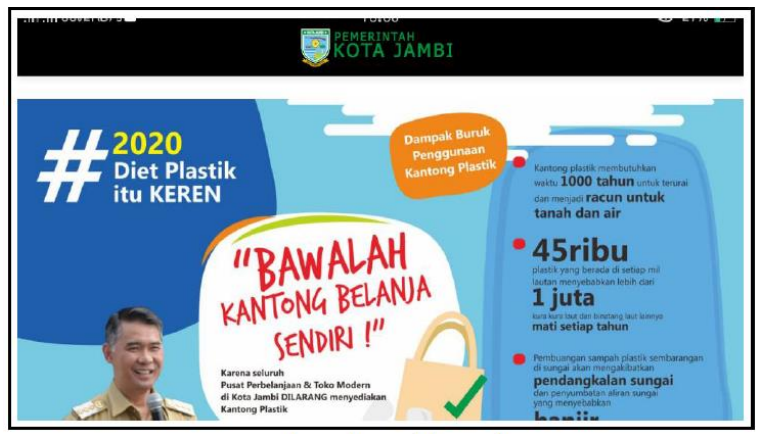

Sumber: Website Kota Jambi

Gambar 5: Postingan websitejambikota.go.id

\section{Pengaruh Kebijakan}

Pemerintah Kota Jambi melalui Dinas Lingkungan Hidup (DLH) telah melakukan sosialisasi pembatasan penggunaan kantong plastik. Pembatasan penggunaan kantong plastik di kota Jambi berdasarkan peraturan daerah Kota Jambi Nomor 8 Tahun 2013 tentang pengelolaan sampah. Selain itu, Peraturan Walikota Jambi Nomor 54 tahun 2018, tentang kebijakan dan strategi Kota Jambi dalam pengelolaan sampah rumah tangga dan sampah sejenis rumah tangga, serta Peraturan Walikota Jambi Nomor 61 tahun 2018, tentang pembatasan penggunaan kantong plastik. Penggunaan kantong plastik ini telah dilaksanakan sejak 1 Januari 2019. Pelaksanaan kebijakan ini pertama kali diterapkan pada pelaku usaha ritel, took modern, dan pasar modern. Kemudian, kebijakan ini diterapkan pada took-toko kecil hingga penjual di pinggir jalan.

Pelaksanaan kebijakan ini dilakukan selama 3 bulan sebagai tahap awal evaluasi (Ardi, 2020), kemudian apabila pihak ritel masih melakukan penggunaan kantong plastik maka perizinannya akan ditinjau ulang. Pelaksanaan kebijakan ini tentunya dilakukan secara bertahap karena tidak mudah untuk mengedukasi masyarakat yang telah melakukan kebiasaan menggunakan kantong plastik selama berpuluh-puluh tahun lamanya. 
Pelaksanaan kebijakan ini juga menggerakkan banyak pihak diantaranya dari pihak kecamatan, kelurahan, hingga ketua RT. Sehingga informasi tentang kebijakan ini bisa terserap dengan baik dan dilaksanakan tanpa adanya polemik di masyarakat.

Apabila kebijakan pembatasan penggunaan kantong plastik ini berjalan dengan lancar, maka pada tahun 2025 sampah di kota Jambi khususnya kantong plastic akan berkurang 30\%. Sehingga harapan Pemerintah kota Jambi untuk mewujudkan kota Jambi yang bersih, nyaman, dan ramah lingkungan akan terwujud. Kebijakan ini akan terlaksana dengan baik apabila masyarakat Kota Jambi mentaati aturan yang telah di buat oleh Pemerintah yakni selalu membawa kantong yang ramah lingkungan sebagai pengganti dari kantong plastik.

\section{SIMPULAN DAN SARAN}

Upaya Pemerintah Kota Jambi dalam mengkomunikasikan kebijakan pembatasan penggunaan kantong plastik sesuai Peraturan Walikota Jambi Nomor 61 Tahun 2018, melalui kegiatan Forum Group Discussion (FGD), melalui Sosialisasi bersama stakeholder, para pihak terkait, dan melalui himbau dan kampanye. Media yang digunakan adalah bauran media yaitu media elektronik, media cetak, dan media sosial. Pengaruh kebijakan akan mengurangi penggunaan kantong plastik hingga $30 \%$ sehingga dapat mewujudkan kota Jambi yang bersih, nyaman, dan ramah lingkungan.

Selanjutnya disarankan kepada Pemerintah Kota Jambi untuk (1) memperketat pengawasan terhadap iplementasi peraturan pembatasan penggunaan plastic tersebut, (2) mengukur efektifitas sosialisasi kebijakan pembatasan Penggunaan kantong plastik secara ilmiah melalui survei indek kepuasan masyarakat (IKM) dan (3) melakukan evaluasi terhadap kebijakan yang telah diterapkan.

\section{UCAPAN TERIMAKASIH}

Ucapan terimakasih disampaikan kepada semua pihak yang telah mendukung penyelesaian artikel ini. Khususnya ucapan terima kasih penulis ucapkan kepada Dr. Ardi, SP, M.Si Kepala Dinas Lingkungan Hidup Kota Jambi, Kepala Bagian Humas Pemerintah Kota Jambi dan juga semua pihak yang telah memberi infromasi kepada peneliti, dan juga temen-teman prodi IImu Komunikasi Universitas Nurdin Hamzah yang telah berpastisipasi dalam penyusunan artikel ini semoga menjadi ladang amal jariyah.

\section{DAFTAR PUSTAKA}

Bungin, Burhan. (2006). Sosiologi Komunikasi, Teori, Paradigma, dan Diskurus Teknologi Komunikasi di Masyarakat. Jakarta: Penerbit Kencana Prenada Media Group.

DeFleur, Melvin L. Foundamental of Human Communikcation. Toronto: Mayfield Publisting Company.

Dinas Lingkungan Hidup Kota Jambi. (2017). Rencana Strategis Dinas Lingkungan Hidup Pemerintah Kota Jambi Tahun 2013-2018. Kota Jambi: Dinas Lingkungan Hidup Pemerintah Kota Jambi. 
Dinas Lingkungan Hidup Kota Jambi. (2018). Laporan Kinerja Dinas Lingkungan Hidup Pemerintah Kota Jambi Tahun 2018. Kota Jambi: Dinas Lingkungan Hidup Pemerintah Kota Jambi.

Dye, Thomas R.. (1992). Understanding Public Policy. Prince Hall, Englewood Cliffs, New Jersey. United State of America.

Edward III, George C. (1980). Implementing Public Policy.Washington DC:Congresional Quarterly Press.

Ekawati, Sulisty. (2016). Mengkritisi Kebijakan Penanganan Kantong Plastik di Indonesia. Jurnal Police Brief, Volume 10, No.6.

Endraswara, S. (2006). Metode, Teori, Teknik, Peneltian Kebudayaan: Ideologi, Epistimologi, dan Aplikasi. Yogyakarta: Pustaka Widyatama.

Ettredge, M., Richardson, VJ., and Scholz, S. (2001). "The presentation of financial information at corporate website", International Journal of Accounting Information Systems, Vol. 2: 149-168.

Hayatullah, Kurniadi dan Hizasalasi, Mohamad. (2017). Strategi Komunikasi dalam Kampanye Diet Kantong Plastik oleh GIDKP di Indonesia. Jurnal Medium, Volume 6 Nomor 1.

Iskandar. (2009). Metologi Penelitian Kualitatif. Jakarta: Gaung Persada.

Jasrianto, Dori. "Implementasi Keterbukaan Infromasi Publik Melalui Sistem Infromasi Manajmemn Pendidikan”. Jurnal FISIP Universitas Diponegoro Semarang.

Karuniastuti, Nurhenu. (2017). Bahaya plastik terhadap kesehatan dan lingkungan. Jurnal Forum Tekhnologi. Volume. 03. Nomor. 01.

Kountur, Ronny. (2007). Metode Penelitian untuk Penulisan Skripsi, dan Thesis. Jakarta: PT Gramedia Press.

Liliweri, Alo. (2004). Wacana Komunikasi Organisasi. Bandung: Penerbit Mandar Maju.

Morisan. (2013). Teori Komunikasi, Indvidu Hingga Massa. Jakarta: Penerbit Kencana Prenada Media Group.

Nurhenu, Karuniastuti. (2013). "Bahaya plastik terhadap kesehatan dan lingkungan”. Jurnal Forum Tekhnologi . Volume. 03. Nomor. 01.

Pembayun, Galih Kuncoro. (2017). "Analisis Implementasi Kebijakan Keterbukaan Infromasi Publik Pada Badan Perpustakaan Dan Kerasipan Daerah Provinsi Jawa Barat”. Jurnal Politik Pemerintahan Volume 10, No.1.

Prastowo, Andi. (2012). Metode Penelitian Kualitatif dalam Perspektif Rancangan Penelitian. Jakarta: Ar-ruzz Media.

Rahayu, lin Tri dan Ardani, Tristiadi Ardi. (2004). Observasi dan Wawancara. Jatim: Bayu Media Publishing.

Suminar, Soemirat, Ardianto. (2017). "Komunikasi Organisasi”. Unpublished: Tesis. Universitas Terbuka, Jakarta.

Undang-Undang Nomor 14 Tahun 2008 Tentang Keterbukaan Informasi Publik.

Williams, S.M., C.H.W. Pei. (2001). "Corporate social disclosure by Listed companies on their web sites: an international comparison", International Journal of Accounting, Vol. 34, N.3: 389-419. 